\title{
SOCIO-ECONOMIC STATUS, DIETARY HABITS AND HEALTH-RELATED OUTCOMES IN VARIOUS PARTS OF THE WORLD: A REVIEW
}

\author{
Konstantinos Vlismas, Vassilios Stavrinos, Demosthenes B. Panagiotakos \\ Department of Nutrition-Dietetics, Harokopio University of Athens, Athens, Greece
}

\begin{abstract}
SUMMARY
It is generally accepted that socio-economic status (SES) influences dietary habits as well as human health. Three main parameters have been most often used to define SES, i.e. occupation, education and income. These characteristics cover different aspects of the socio-economic structure of people. The aim of this review is to present the current knowledge regarding the relationships between SES, dietary habits and health-related outcomes in various parts of the world.
\end{abstract}

Key words: socio-economic status, diet, disease, health, education, occupation, income

Address for correspondence: D. B. Panagiotakos, 46 Paleon Polemiston St., 166 74, Attica, Greece. E-mail: d.b.panagiotakos@usa.net

\section{INTRODUCTION}

Socio-economic status (SES) is a well-established term often included in dietary studies as an explanatory variable in the analysis of another dependent variable such as health status (1). The definition and measurement of SES with respect to diet and health research has been critically examined in recent years (1-5). In order to characterise SES, three variables have been used most often: occupation, education and income. Although these variables measure the same concept it has been suggested that they cover different aspects of the socio-economic structure contributing individually to the relationship between SES and diet $(4,5)$.

Education is considered to be related to health outcomes through its influence on lifestyle behaviours (e.g., exercise, diet), problem-solving capacity and values (e.g. importance of preventive health behaviours) (1). Moreover, education may facilitate the acquisition of positive psycho-social and economic skills and may provide protection from adverse influences (6). The main advantages of education are that it is relatively easy to assess in self-administered questionnaires and response rates to educational questions tend to be high as these can be obtained from everybody independently of age or working circumstances (3).

Occupation in developed societies measures prestige, responsibility, physical activity and work exposures (6). Occupation may also affect diet by creating environmental or social networks that can influence behavioural health habits (4). Finally, more advantaged occupational levels permit increased access to medical care, enable one to have the funds for better housing and better nutrition, to live in safer neighbourhoods and increase his/her opportunity to engage in health-promoting behaviours (7).

Income is likely to mirror the availability of economic and material resources, and therefore influences dietary quality by making healthy food more or less affordable and accessible (8).
The choice of socio-economic indicator often reflects which data are obtainable. In the US, measures based upon education have been widely used, because such information is the main socio-economic indicator contained in various national data sets (9). The Registrar General's classification of social class based on occupational status has traditionally been used to describe 'inequalities' of health in Great Britain (10).

The relationship between SES and diet or disease has been investigated by studying mortality rates for chronic diseases, food and nutrient intake, dietary patterns and food behaviour. It seems that disadvantaged groups have dietary profiles that increase mortality and morbidity rates for chronic diseases and they do not comply with recommended daily nutrient intakes and dietary guidelines, thus increasing the risk for development of chronic diseases (11-18).

Analysis of dietary patterns, as an approach to investigating links between diet and disease or diet and SES in relation to health risks has received a lot of attention from researchers and is indeed important, since it recognizes that foods are consumed in many combinations that are likely to be complex, and that nutrient intakes are often highly correlated with certain nutrients having interactive and synergistic effects (19-22). Investigation of dietary patterns also provides advantages with respect to the development of public health nutrition messages (23). In addition, dietary patterns could be used as a covariate in the analysis of individual dietary factors to determine whether there is an effect of the dietary factor independent of the overall dietary pattern (24) but overall direct comparison of the dietary patterns identified by different studies is difficult due to methodological differences (23).

The aim of this review is to highlight the most characteristic types of studies relating SES with diet and/or disease according to geographical distribution, to discuss current limitations and to propose recommendations for future research. 


\section{WEST EUROPE, USA, AUSTRALIA, CANADA}

Pomerleau J. et al. (25), in an effort to investigate health behaviour in a Canadian population used data from the 1990 Ontario Health Survey. The survey used a multi-stage cluster design to select a sample of about 1,000 households from each of 42 public health units. Data were collected using an interview with one knowledgeable member of the selected household (covering the socio-demographic characteristics, health status, contacts with health professionals, use of medication, medical insurance, and accidents and injuries of all household members; response rate $=87 \%$ ) and self-administered questionnaires (covering lifestyle, health problems, and the use of prescription and non-prescription drugs of each individual age 12 years and over; response rate = 77\%). The survey sample was 61,239 individuals (representing about 10 million persons). Information from all respondents 19 years (legal drinking age in Ontario) and over was used in the analyses $(n=43,099)$. Four measures of socio-economic status were used: educational achievement, household income status, source of household income and occupational prestige, in order to explore the association with 'unhealthy' behaviours, like smoking, fat intake $>30 \%$ of dietary energy, alcohol intake $>14$ units per week, and low level of leisure-time physical activity. Except for the positive relationship between income status and high alcohol intake, the investigated measures of 'unhealthy' behaviours were inversely associated with the above socio-economic indices, suggesting that individuals in lower socioeconomic groups were at an increased risk for health problems (25).

Hazuda HP. et al. (26) in the San Antonio Heart Study investigated the effects of acculturation and SES on obesity and diabetes among Mexican Americans. Subjects were selected from three socio-culturally distinct neighbourhoods in San Antonio, Texas: a low income, exclusively Mexican-American neighbourhood; a middle-income neighbourhood containing approximately equal numbers of Mexican Americans and non-Hispanic whites; and an upper-income neighbourhood consisting of approximately 10\% Mexican Americans and 90\% non-Hispanic whites. Persons eligible for study were defined as all 25 to 64 year-old men and non-pregnant women residing in households randomly selected within each neighbourhood. The overall response rate was $61.3 \%$ in the barrio, $60.1 \%$ in the transitional neighbourhood, and 69.5\% in the suburbs. The report was based on 1,288 Mexican Americans and 929 non-Hispanic whites. SES was assessed by the Duncan Socio-economic Index and acculturation was assessed by three scales which measure functional integration with mainstream society, value placed on preserving Mexican cultural origin, and attitude toward traditional family structure and sex-role organisation. The results of this study support the hypothesis that acculturation and SES exert parallel influences on obesity and diabetes in Mexican Americans. Increases in either component of socio-cultural status were, in general, associated with decreases in obesity and diabetes. However, acculturation appeared to exert a more powerful influence on these outcomes than did SES. The latter was significantly related to obesity and diabetes only in women, while acculturation was significantly related to these outcomes in both sexes (26).

Galobardes B. et al. (4) highlighted the functionality of education and occupation as individual but also synergistic SES indicators in a community-based random sample of men and women residents of Geneva canton, aged 35 to 74 years, who participated in a survey of cardiovascular risk factors conducted annually since 1993. Lifetime occupational and educational history and a semi-quantitative food frequency questionnaire (FFQ) were obtained from 2,929 men and 2,767 women. Subjects from lower education and/or occupation consumed less fish and vegetables but more fried foods, pasta and potatoes, table sugar and beer. Iron, calcium, vitamin A and vitamin D intakes were lower in the lower educational and occupational groups. The results showed that lower education and lower occupation independently contribute to determining differences in dietary habits and that the effect of the two indicators is cumulative for some nutrients suggesting that both indicators should be assessed so as to provide a full description of social inequalities in dietary habits (4).

Bolton-Smith C. et al. (17) in a cross-sectional study (Scottish Heart Health Study) of coronary heart disease (CHD) risk factors used food frequency questionnaire and socio-demographic data that were collected from over 10,000 Scottish men and women aged $40-59$ years, to assess dietary intake, including the antioxidant vitamins $\mathrm{C}$ and $\mathrm{E}$ and $\beta$-carotene, for different socioeconomic groups. Classification by occupation was performed according to the coding index of the Office of Populations, Censuses and Surveys (OPCS), 1980 and by grouping into nonmanual (N; I, II, IIIN) and manual (M; IIIM, IV, V) occupations. Women were grouped according to their husband's occupation and the currently unemployed by their last job. The overall response rate was $74 \%$. Overall, men and women in manual occupations had a poorer quality diet than did those in non-manual occupations. The coincident low P:S ratios and low antioxidant vitamin intakes in manual groups may contribute to an increased risk of CHD (17).

In Netherlands, Hushof KF. et al. (27) in a cross sectional study based on data of three Dutch National Food Consumption Surveys (a total of 6,008 men and 6,957 women aged 19 years and over) studied the differences in dietary intake between adults with different SES and trends over time. Dietary intake was assessed with a two-day dietary record and SES was based on educational level, occupation and occupational position and was categorized into (very) low, middle and high. Analysis of variance with age as co-variable was used to explore the effects of SES on dietary intake and anthropometry. The prevalence of obesity and skipping of breakfast was higher among people with a low SES. Regarding nutrient intake, in all surveys a higher SES was associated with higher intake of vegetable protein, dietary fibre and most micronutrients. In general, dietary intake among subjects in higher SES groups tended to be closer to the recommendations of the Netherlands Food and Nutrition council and this phenomenon was quite stable over a decade (27).

In a different cross-sectional self-report population survey, Mishra G. et al. (19) used data provided by 6,680 adults aged 18-64 years who participated in the 1995 Australian National Nutrition Survey (NNS) to describe dietary patterns among men and women in the Australian population, and to explore how these varied according to SES. Employment was used as an index of SES. The measure of employment used in the present analyses was a multi-dimensional item derived empirically through gender-specific factor analyses of demographic and socio-economic variables included in the National Health Survey. Items encompassed by the employment factor included measures of employment status, oc- 
cupation and hours worked. The employment factor was split into tertiles, with the lowest representing the most disadvantaged, and the highest representing the most socio-economically advantaged. Factor analyses were used to analyse data from a FFQ completed by participants. Separate factor analyses of the FFQ data for men and women revealed 15 factors, accounting for approximately $50 \%$ of the variance in both men's and women's dietary patterns. Several gender and SES differences in food patterns were observed. Lower SES males more frequently consumed 'tropical fruits', 'protein foods', and 'offal and canned fish', while high SES males more often ate 'breakfast cereals' and 'wholemeal bread'. Lower SES females more often ate 'traditional vegetables', 'meat dishes' and 'pasta, rice and other mixed foods', while high SES females more frequently ate 'ethnic vegetables' and 'breakfast cereal - muesli'. These findings highlight the complexity of the associations between SES and different components of dietary intake and contribute to a better understanding of the dietary patterns that underscore gender-specific SES differences in nutrient intakes (19).

A recent study by Turrell G. and Kavanagh A.M. (8) examined the association between education level and food purchasing behaviour and the contribution of dietary knowledge to this relationship, the association between household income and purchasing behaviour and the contribution made by subjective perceptions about the cost of healthy food. The study was conducted in Brisbane City (Australia) in 2000. The sample was selected using a stratified two-stage cluster design. Data were collected by face-toface interviews from residents of private dwellings $(n=1,003)$, and the response rate was $66.4 \%$. Dietary knowledge was measured using a 20-item index that assessed general knowledge about food, nutrition, health and their interrelationships. Food cost concern was measured using a three-item scale derived from principal components analysis $(\alpha=0.647)$. Food purchasing was measured using a 16-item index that reflected a household's purchase of grocery items that were consistent (or otherwise) with dietary guideline recommendations. Food shoppers with low levels of education, and those residing in low-income households, were least likely to purchase foods that were comparatively high in fibre and low in fat, salt and sugar. Socio-economic differences in dietary knowledge represented part of the pathway through which educational accomplishment exerts an influence on diet and also that food purchasing differences by household income were related to diet in part via food-cost concern. Findings suggest that socio-economic differences in food purchasing behaviour may contribute to the relationship between socio-economic position and food and nutrient intakes, and, by extension, to socio-economic health inequalities for diet-related disease (8).

Finally, a cross sectional survey linked with environmental data by Ball K. et al. (28) employed a multilevel design to test the contribution of individual, social and environmental factors to mediate SES inequalities in fruit and vegetable consumption among women. In total, 1,347 women from 45 neighbourhoods in Melbourne provided survey data on their SES (highest education level), nutrition knowledge, health considerations related to food purchasing, and social support for healthy eating. These data were linked with environmental data on the density of supermarkets and fruit and vegetable outlets in local neighbourhoods and it showed that fruit and vegetable intakes tended to be higher among women with higher levels of education, older women, and (for vegetables only) women who were married or living in de facto relationships. Intakes were also higher among women reporting greater health considerations, those with higher nutrition knowledge scores (vegetables only), and those with greater family and friend support for healthy eating. Store density did not mediate the relationship of SES with fruit or vegetable consumption. Multilevel modelling showed that individual and social factors partly mediated, but did not completely explain, SES variations in fruit and vegetable consumption (28).

\section{EAST EUROPE}

In East Europe, socio-economic status and its relation to health have been investigated mainly in Poland (29-31) and the Czech Republic (32-35) with few exceptions such as Russia (36) and Hungary $(37,38)$. However, studies relating diet, socio-economic and health status are limited (39).

For example, in a recent study, Murphy M. et al. (36) examined trends in the relation between educational level and adult mortality in the Russian Federation in the period 1989 through 2001. A convenience cohort based on survey respondents' information about age, survival status, and educational level of close relatives was used and modified indirect demographic techniques to stratify mortality rates by educational level in the study period was applied. A random sample of 7,172 respondents (response rate $=61 \%$ ) provided full information on 10,440 relatives. The well-documented mortality increases seen in Russia after 1990 have predominantly affected less-educated men and women, whereas the mortality of persons with university education has improved, resulting in a sharp increase in educational-level mortality differentials (36).

\section{ASIA}

Islam MZ. et al. (40) in a cross sectional study used three-day dietary records to estimate habitual calcium intake in two socioeconomic groups (high and low) in women in Bangladesh (a total of 191 subjects of Bangladeshi women aged 16-40 years). The mean dietary calcium intake was significantly higher in the high income group but even in the high income group $47 \%$ of subjects failed to meet the lowest level (400-500 mg/day) of WHO recommended dietary allowances (RDA) of calcium for adult women. No subject in the low-income group was found to meet the RDA level. Moreover, $63 \%$ of the women in the low-income group had calcium intake lower than $200 \mathrm{mg} /$ day. The results of the study suggested that low calcium intake could reduce the bone accretion rates and increase the risk of osteoporosis in the subjects of the present study concluding that calcium rich food may be recommended for women in both groups (40).

In addition, Le Ngoc Dien et al. (41) investigated Vietnamese food consumption patterns, in terms of food quantity and total energy intake, and examined how these food patterns differ by demography and SES. Data used in this study were derived from the Vietnam Living Standards Survey national cross-sectional study in 1997-1998. Descriptive and regression analyses identified different food consumption patterns among 5,999 participating households. The regression models identified place of residence, 
family income, household size, education of the head of household, ethnicity, and ecological region to be significantly associated with energy intake. Characteristically, $46 \%$ of the whole population consumed less than $2,100 \mathrm{kcal} /$ day. It was concluded that socio-economic and demographic status must be considered in developing national strategies and implementing plans of action to improve nutrition and it is important to establish a food subsidy program to provide more food, particularly animal products, to the poor, the ethnic minorities and the rural residents (41).

Hui-Guang Tian et al. (42), studied the relationship between dietary sodium, potassium, socio-economic status and blood pressure in a Chinese population. In all, 1,804 men with mean age 38.4 years and 1,878 women with mean age 38.8 years were studied. The participant's educational level was classified into one of three categories according to years of education and occupation was classified into five categories: farmer, blue-collar worker, white-collar worker, housewife or retired person, and service worker. Both household inventory and consecutive three-day individual food records were used to collect dietary data in the survey. Sodium intake decreased with increasing level of education in men but both intakes exceeded dietary recommendations. More educated men and women had lower intakes of salt and soy sauce and higher intake of monosodium glutamate (MSG) compared with less educated persons, except for soy sauce intake in women. The associations were stronger when men with highest and lowest levels of education were compared $(\mathrm{p}<0.001)$. An inverse relationship between blood pressure and education was found in both genders but the association was stronger in women than in men. Average systolic blood pressure in men with the highest education was $3 \mathrm{mmHg}$ lower than among men with the lowest education $(\mathrm{p}<0.05)$, this difference being $7 \mathrm{mmHg}$ in women $(p<0.001)$. The results suggested that information on SES is valuable for identifying those populations at risk of high blood pressure and in the design and implementation of appropriate intervention measures such as reduction in sodium intake for nutritional control of hypertension in population-based interventions aimed at all social classes (42).

In a cross sectional survey in China by Shi Z. et al. (43) an effort to identify the differences in food habits and preferences among adolescents according to socio-demographic characteristics was made using a self-administered questionnaire containing questions on food and meal frequencies, food preferences and sociodemographic characteristics in 824 young adolescents (12-14 years). Socio-demographic characteristics included household SES, parent's educational level, urban/rural and family size and multivariate linear regression analysis (stepwise) was performed to model the association between food intakes and socio-demographical factors. High SES and urban residence was positively associated with intake of high-energy foods, such as foods of animal origin, Western style foods and dairy products. Daily fruit consumption was fairly common, but with clear differences by SES. Only about $42 \%$ of the boys and $55 \%$ of the girls from low SES families ate fruit daily, compared with $66 \%$ and $72 \%$, respectively belonging to the high SES families. Although the sample size was very small, results suggested that nutrition education for adolescents and parents is needed to promote healthy eating considering that although the present intake of Western foods is low, one may expect that with the development of the economy this number may increase dramatically and health authorities should strengthen the monitoring of food intake and its association with overweight/obesity (43).

\section{REST OF THE WORLD}

In a study by Larrea C. and Kawachi I. (44) the association between economic inequality and child malnutrition in Ecuador was examined. Economic inequality was measured by the Gini coefficient of household per capita consumption, estimated from the 1990 Census. Childhood stunting, assessed from height-forage z scores, was obtained from the 1998 Living Standards Measurement Survey (LSMS). Both maternal education and housing conditions affect child nutrition, and are indicative of household socio-economic status. Maternal education was assessed by the number of years of schooling, while housing conditions were summarized by a multivariate index, based mostly on living conditions and facility availability. Results showed that maternal education, basic housing conditions, access to health services, ethnicity, fertility, maternal age and diet composition was independently associated with stunting. However, after controlling for relevant covariates, economic inequality at the provincial scale had a statistically significant deleterious effect on stunting [44].

\section{CONCLUSIVE REMARKS}

SES is a complex phenomenon predicted by a broad spectrum of variables that is often conceptualised as a combination of financial, occupational, and educational influences (6). It is not useful to search for a single 'best' indicator of SES as each indicator covers a different area of social stratification, which may be relevant to different health outcomes and at different stages in the life course (3). However, if financial and time parameters leave no choice but to use one SES variable, the study of Winkleby MA. et al. (6) suggests that education, rather than income or occupation, may be the strongest and most consistent predictor of good health.

Given the respective limitations of each of these indicators and the lack of agreement over how best to combine different measures into a single index (1), four separate variables were used to assess SES in the study of Pomerleau J. et al. (25). Of these, educational achievement appeared to be the strongest and most consistent predictor of 'unhealthy' lifestyle behaviours whereas in the San Antonio Heart Study (26) which was based on individual level data and used separate measures of acculturation and socioeconomic status showed that cultural factors play a more pervasive role in the development of obesity and diabetes among Mexican Americans than do purely socio-economic factors. Moreover, Galobardes et al. (4) using education and occupation as SES indicators showed that lower education and lower occupation contribute independently to determining differences in dietary habits and that their effect is synergistic thus highlighting that several indicators are needed to fully capture someone's socio-economic status. However, results of Turrell G. and Kavanagh AM. (8), suggest that simultaneous adjustment for multiple socio-economic indicators can introduce its own inherent problems as analytical models that are not clearly specified run the risk of 'over-adjusting'.

A potential limitation of most nationwide population surveys 
Table 1. Socio-economic status, dietary characteristics and health outcomes around the world

\begin{tabular}{|c|c|c|c|c|c|}
\hline Study & Design & SES characteristics & $\begin{array}{c}\text { Dietary } \\
\text { characteristics }\end{array}$ & Health characteristics & Conclusion \\
\hline \multicolumn{6}{|c|}{ Studies evaluated the association between SES, dietary habits and health outcomes in West Europe, USA, Australia and Canada } \\
\hline $\begin{array}{l}\text { Pomerleau J. } \\
\text { et al., } 1997\end{array}$ & $\begin{array}{l}\text { Cross-sectional survey } \\
\mathrm{n}=43,099 \text { men and } \\
\text { women } 19+\text { years } \\
\text { Data from the } 1990 \\
\text { Ontario Health Survey }\end{array}$ & $\begin{array}{l}\text { Educational achieve- } \\
\text { ment, household income, } \\
\text { source of household } \\
\text { income, occupational } \\
\text { prestige }\end{array}$ & $\begin{array}{l}\text { Unhealthy behaviours } \\
\text { (smoking, fat intake } \\
>30 \% \text { of dietary energy, } \\
\text { alcohol intake >14 units } \\
\text { per week, low level of } \\
\text { leisure-time physical } \\
\text { activity) }\end{array}$ & & $\begin{array}{l}\downarrow \text { LES } \uparrow \text { risk for unhealthy } \\
\text { behaviours, educational } \\
\text { achievement appeared } \\
\text { to be the strongest and } \\
\text { most consistent predictor } \\
\text { of 'unhealthy' lifestyle } \\
\text { behaviours }\end{array}$ \\
\hline $\begin{array}{l}\text { Hazuda H. et } \\
\text { al., } 1988 \\
\text { (The San } \\
\text { Antonio Heart } \\
\text { study) }\end{array}$ & $\begin{array}{l}\text { Population-based } \\
n=1,288 \text { Mexican } \\
\text { Americans and } 929 \text { non- } \\
\text { Hispanic whites } 25 \text { - to } \\
64 \text {-year-old men and } \\
\text { non-pregnant women }\end{array}$ & $\begin{array}{l}\text { SES: Duncan Socioeco- } \\
\text { nomic Index Accultura- } \\
\text { tion: Functional integra- } \\
\text { tion with mainstream } \\
\text { society, value placed on } \\
\text { preserving Mexican cul- } \\
\text { tural origin, and attitude } \\
\text { toward traditional family } \\
\text { structure and sex-role } \\
\text { organization }\end{array}$ & $\begin{array}{l}\text { Obesity and diabetes } \\
\text { prevalence }\end{array}$ & $\begin{array}{l}\text { Increased obesity and } \\
\text { diabetes prevalence for } \\
\text { low SES and accultura- } \\
\text { tion }\end{array}$ & $\begin{array}{l}\text { Men: } \uparrow \text { Acculturation } \\
\downarrow \text { \obesity and diabetes } \\
\text { No effect of SES } \\
\text { Women: } \\
\uparrow S E S \uparrow \text { Acculturation } \\
\downarrow \text { obesity and diabetes }\end{array}$ \\
\hline $\begin{array}{l}\text { Galobardes } \\
\text { B. et al., } 2001 \\
\text { (Bus Sante } \\
2000 \text { Survey) }\end{array}$ & $\begin{array}{l}\text { Community-based } \\
\text { random sample of men } \\
\text { and women from Geneva } \\
\text { canton aged } 35-74 \text { years } \\
\text { ( } n=2,929 \text { men } n=2,767 \\
\text { women) }\end{array}$ & $\begin{array}{l}\text { Education (low, medium, } \\
\text { high) } \\
\text { Occupation (British Re- } \\
\text { gistrar General's Scale) }\end{array}$ & $\begin{array}{l}\text { Self-administered, } \\
\text { semi-quantitative food } \\
\text { frequency questionnaire } \\
\text { (FFQ) (100 food items } \\
\text { and serving sizes), } \\
\text { dietary habits }\end{array}$ & $\begin{array}{l}\text { Increased health risk for } \\
\text { low SES groups }\end{array}$ & $\begin{array}{l}\text { Men: } \downarrow S E S \downarrow \text { fish and } \\
\text { vegetables } \uparrow \text { pasta, } \\
\text { potatoes, fried foods and } \\
\text { beer } \\
\text { Women: } \downarrow \text { SES } \downarrow \text { fish } \\
\text { and vegetables } \uparrow \text { pasta, } \\
\text { potatoes fried foods, } \\
\text { meat, table sugar } \\
\text { Independent but also } \\
\text { cumulative effect of } \\
\text { education and occupation }\end{array}$ \\
\hline $\begin{array}{l}\text { Bolton-Smith } \\
\text { C. et al., } 1991 \\
\text { (Scottish Heart } \\
\text { Health Study) }\end{array}$ & $\begin{array}{l}\text { Cross-sectional study } \\
n=10,359 \text { men and } \\
\text { women aged } 40-59 \\
\text { years }\end{array}$ & $\begin{array}{l}\text { Occupation: coding } \\
\text { index of the Office of } \\
\text { Populations, Censuses } \\
\text { and Surveys (OPCS) } \\
\text { (non-manual, manual } \\
\text { occupations). Women } \\
\text { were grouped accord- } \\
\text { ing to their husband's } \\
\text { occupation and the } \\
\text { currently unemployed by } \\
\text { their last job. Alternative } \\
\text { classification according } \\
\text { to housing tenure (owner, } \\
\text { occupier, local authority } \\
\text { rented (LAR) and private } \\
\text { rented) and by level } \\
\text { of education (primary, } \\
\text { secondary, professional } \\
\text { and university) }\end{array}$ & $\begin{array}{l}\text { Questionnaire (social } \\
\text { factors, health, smoking, } \\
\text { exercise and diet). Diet } \\
\text { was assessed using } \\
\text { a modified version of } \\
\text { the food frequency } \\
\text { questionnaire (FFQ) } \\
\text { which was established } \\
\text { by the Medical Research } \\
\text { Council Cardiff Group } \\
\text { Physical examination } \\
\text { (weight, height, blood } \\
\text { pressure measurement } \\
\text { and a non-fasted venous } \\
\text { blood sample) Half of } \\
\text { the sampling was carried } \\
\text { out during the summer } \\
\text { months and another half } \\
\text { during the winter months }\end{array}$ & CHD risk factors & $\begin{array}{l}\downarrow \text { SES } \downarrow \text { low P:S ratios } \\
\text { and low antioxidant } \\
\text { vitamin intakes } \uparrow \text { risk of } \\
\text { CHD }\end{array}$ \\
\hline
\end{tabular}


Table 1. cont.

\begin{tabular}{|c|c|c|c|c|c|}
\hline $\begin{array}{l}\text { Hushof KF. et } \\
\text { al., } 2003\end{array}$ & $\begin{array}{l}\text { Cross-sectional study } \\
\mathrm{n}=6,008 \text { men and } 6,957 \\
\text { women } 19+\text { years. Data } \\
\text { obtained from three } \\
\text { Dutch National Food } \\
\text { Consumption Surveys } \\
\text { (DNFCS-1 1987=88; } \\
\text { DNFCS-2 1992; DNFCS- } \\
3 \text { 1997=98) }\end{array}$ & $\begin{array}{l}\text { Education, } \\
\text { Occupation } \\
\text { Occupational position } \\
\text { (high medium, low and } \\
\text { very low) }\end{array}$ & $\begin{array}{l}\text { The food intake data } \\
\text { were collected through } \\
\text { a } 2 \text { day dietary record } \\
\text { method (food consump- } \\
\text { tion data on the individual } \\
\text { level were converted into } \\
\text { energy and nutrients } \\
\text { using the most up-to-date } \\
\text { version of the Dutch food } \\
\text { composition table) } \\
\text { Background information } \\
\text { was obtained by struc- } \\
\text { tured questionnaire }\end{array}$ & $\begin{array}{l}\text { Obesity prevalence for } \\
\text { low SES groups }\end{array}$ & $\begin{array}{l}\uparrow \text { SES Dietary intake } \\
\text { tended to be closer to the } \\
\text { recommendations of the } \\
\text { Netherlands Food and } \\
\text { Nutrition Council (quite } \\
\text { stable over a period of } \\
10 \mathrm{y} \text { ) }\end{array}$ \\
\hline $\begin{array}{l}\text { Mishra G. et } \\
\text { al., } 2002\end{array}$ & $\begin{array}{l}\text { Cross-sectional survey } \\
\mathrm{n}=6,680 \text { adults ( } 3,111 \\
\text { men and 3,569 women) } \\
\text { aged } 18-64 \text { years Aus- } \\
\text { tralian National Nutrition } \\
\text { Survey (NNS) }\end{array}$ & $\begin{array}{l}\text { Gender-specific employ- } \\
\text { ment factor including } \\
\text { employment status, occu- } \\
\text { pation and hours worked }\end{array}$ & $\begin{array}{l}\text { Self-reported FFQ as- } \\
\text { sessed usual frequency } \\
\text { of intake of } 100 \text { food and } \\
\text { non-alcoholic beverage } \\
\text { items over the last } 12 \\
\text { months. } 15 \text { dietary-pat- } \\
\text { tern factors identified } \\
\text { accounted for around } \\
50 \% \text { of variance for both } \\
\text { males and females }\end{array}$ & & $\begin{array}{l}\text { Men: } \downarrow \text { SES } \downarrow \text { 'breakfast } \\
\text { cereals' and 'wholemeal } \\
\text { bread' } \uparrow \text { 'tropical fruits', } \\
\text { 'protein foods' and 'offal } \\
\text { and canned fish' } \\
\text { Women: } \downarrow \text { SES } \downarrow \\
\text { 'ethnic vegetables' and } \\
\text { 'breakfast cereal/muesli' } \uparrow \\
\text { 'traditional vegetables', } \\
\text { 'meat dishes' and 'pasta, } \\
\text { rice and other mixed } \\
\text { foods' }\end{array}$ \\
\hline $\begin{array}{l}\text { Turrell G. and } \\
\text { Kavanagh AM. } \\
2006\end{array}$ & $\begin{array}{l}\mathrm{n}=1,003 \text { (Brisbane City } \\
\text { Australia, 2000) using a } \\
\text { stratified two-stage clus- } \\
\text { ter design and interview } \\
\text { the person within each } \\
\text { dwelling who was prima- } \\
\text { rily responsible for most } \\
\text { of the food shopping }\end{array}$ & $\begin{array}{l}\text { Education } \\
\text { Household Income }\end{array}$ & $\begin{array}{l}\text { Dietary knowledge } \\
\text { (pre-coded structured } \\
\text { question comprising } 20 \\
\text { statements) } \\
\text { Food cost concern (16 } \\
\text { statements that pertained } \\
\text { to health and financial } \\
\text { factors that may have } \\
\text { influenced the house- } \\
\text { hold's food purchasing } \\
\text { decisions) } \\
\text { Food purchasing (exam- } \\
\text { ined on the basis of } 16 \\
\text { grocery foods including } \\
\text { meat and chicken) }\end{array}$ & & $\begin{array}{l}\downarrow S E S \text { less likely to pur- } \\
\text { chase grocery foods that } \\
\text { were high in fibre and low } \\
\text { in fat, salt and sugar } \\
\text { In } \downarrow \text { SES food-cost } \\
\text { concern } \\
\text { represented a barrier to } \\
\text { the purchase of healthy } \\
\text { food }\end{array}$ \\
\hline $\begin{array}{l}\text { Ball K. et al., } \\
2006\end{array}$ & $\begin{array}{l}\text { Cross-sectional survey } \\
\text { women } n=1,347 \text { from } \\
45 \text { neighbourhoods in } \\
\text { Melbourne, Australia } \\
\text { using a stratified } \\
\text { random sampling } \\
\text { procedure }\end{array}$ & $\begin{array}{l}\text { Education (highest } \\
\text { education level) }\end{array}$ & $\begin{array}{l}\text { Self-report survey data on } \\
\text { fruit and vegetable intakes, } \\
\text { nutrition knowledge, } \\
\text { health considerations } \\
\text { related to food purchas- } \\
\text { ing, and social support } \\
\text { for healthy eating. These } \\
\text { data were linked with } \\
\text { objective environmental } \\
\text { data on the density of } \\
\text { supermarkets and fruit } \\
\text { and vegetable outlets in } \\
\text { local neighbourhoods }\end{array}$ & & $\begin{array}{l}\uparrow \text { Fruit and vegetable } \\
\text { intakes in } \uparrow S E S \text {, older } \\
\text { women, in women re- } \\
\text { porting greater health } \\
\text { considerations, those } \\
\text { with higher nutrition } \\
\text { knowledge scores } \\
\text { (vegetables only), and } \\
\text { those with greater family } \\
\text { and friend support for } \\
\text { healthy eating. Multilevel } \\
\text { modelling showed that } \\
\text { individual and social } \\
\text { factors partly mediated, } \\
\text { but did not completely } \\
\text { explain, SES variations } \\
\text { in fruit and vegetable } \\
\text { consumption. Store } \\
\text { density did not mediate } \\
\text { the relationship of SES } \\
\text { with fruit or vegetable } \\
\text { consumption }\end{array}$ \\
\hline
\end{tabular}


Table 1. cont.

\begin{tabular}{|c|c|c|c|c|c|}
\hline \multicolumn{6}{|c|}{ Studies evaluated the association between SES, dietary habits and health outcomes in East Europe } \\
\hline $\begin{array}{l}\text { Murphy M. et } \\
\text { al., } 2006\end{array}$ & $\begin{array}{l}\text { A random sample of } \\
7,172 \text { respondents } \\
\text { provided information on } \\
10,440 \text { relatives a con- } \\
\text { venience cohort based } \\
\text { on survey respondents' } \\
\text { information about age, } \\
\text { survival status, and } \\
\text { educational level of } \\
\text { close relatives, and } \\
\text { applied modified indirect } \\
\text { demographic techniques } \\
\text { to stratify mortality rates } \\
\text { by educational level }\end{array}$ & Education & & Mortality rate & $\begin{array}{l}\downarrow S E S \uparrow \text { mortality } \uparrow \text { edu- } \\
\text { cational-level mortality } \\
\text { differentials }\end{array}$ \\
\hline \multicolumn{6}{|c|}{ Studies evaluated the association between SES, dietary habits and health outcomes in Asia and rest of the world } \\
\hline $\begin{array}{l}\text { Islam MZ. et } \\
\text { al., } 2003\end{array}$ & $\begin{array}{l}\text { Cross sectional study } \\
\mathrm{n}=191 \text { Bangladeshi } \\
\text { women aged } 16-40 \\
\text { years }\end{array}$ & Family income (high, low) & $\begin{array}{l}\text { Dietary intake of calcium } \\
\text { using a } 3 \text { day dietary } \\
\text { record }\end{array}$ & Osteoporosis risk & $\begin{array}{l}\downarrow S E S \downarrow \text { dietary calcium } \\
\text { intake }\end{array}$ \\
\hline $\begin{array}{l}\text { Le Ngoc Dien } \\
\text { et al., } 2004\end{array}$ & $\begin{array}{l}\text { Cross sectional study } \\
\text { Data used from the } \\
\text { Vietnam Living Stand- } \\
\text { ards Survey (VLSS) } \\
\text { 1997-1998 } n=5,999 \\
\text { households }\end{array}$ & $\begin{array}{l}\text { Income quintile, house- } \\
\text { hold size, education of } \\
\text { household-head }\end{array}$ & $\begin{array}{l}\text { Dietary data of the VLSS } \\
97-98 \text { used a standard } \\
\text { array of } 45 \text { food items to } \\
\text { collect the estimated food } \\
\text { quantity consumed by } \\
\text { the household over the } \\
\text { twelve-month period prior } \\
\text { to the survey (through a } \\
\text { dietary recall interview) }\end{array}$ & & $\begin{array}{l}\uparrow \text { family income, } \uparrow \text { energy } \\
\text { consumption from animal } \\
\text { products, } \uparrow \text { energy intake } \\
\text { The percentage of en- } \\
\text { ergy from carbohydrates } \\
\text { was too high }(75.4 \% \text { in } \\
\text { rural areas and } 68.2 \% \text { in } \\
\text { urban areas) }\end{array}$ \\
\hline $\begin{array}{l}\text { Hui-Guang } \\
\text { Tian et al., } \\
1996\end{array}$ & $\begin{array}{l}\text { Dietary survey using a } \\
\text { stratified multilevel } \\
\text { cluster sampling } n=3,682 \\
\text { (1,804 men 1,878 } \\
\text { women) aged } 15-64 \\
\text { years in Tianjin, China }\end{array}$ & $\begin{array}{l}\text { Education (low, middle, } \\
\text { high) } \\
\text { Occupation }\end{array}$ & $\begin{array}{l}\text { Household inventory } \\
\text { and consecutive } 3 \text { day } \\
\text { individual food records } \\
\text { to assess intakes and } \\
\text { sources of dietary sodium } \\
\text { and potassium. Anthropo- } \\
\text { metric data (height, } \\
\text { weight) and weighed food } \\
\text { records were collected }\end{array}$ & Blood pressure & $\begin{array}{l}\uparrow \text { education } \downarrow \text { lower } \\
\text { intakes of salt and soy } \\
\text { sauce } \uparrow \text { intake MSG, } \\
\downarrow \text { average systolic blood } \\
\text { pressure }\end{array}$ \\
\hline $\begin{array}{l}\text { Shi Z. et al., } \\
2005\end{array}$ & $\begin{array}{l}\text { Cross-sectional, cluster } \\
\text { design survey in } 2002 \\
n=824 \text { young adoles- } \\
\text { cents aged 12-14 years } \\
\text { in Jiangsu Province, } \\
\text { China }\end{array}$ & $\begin{array}{l}\text { Household SES score, } \\
\text { parents educational level } \\
\text { and family size }\end{array}$ & $\begin{array}{l}\text { Self-administered food } \\
\text { frequency questionnaire } \\
\text { containing questions on } \\
\text { food and meal frequen- } \\
\text { cies and food prefer- } \\
\text { ences }\end{array}$ & & $\begin{array}{l}\uparrow S E S, \uparrow \text { intake of high- } \\
\text { energy foods, such as } \\
\text { foods of animal origin, } \\
\text { Western style foods and } \\
\text { dairy products, } \uparrow \text { intake } \\
\text { of fruits }\end{array}$ \\
\hline $\begin{array}{l}\text { Larrea C. and } \\
\text { Kawachi I., } \\
2005\end{array}$ & $\begin{array}{l}\mathrm{N}=5,801 \text { households. } \\
\text { Anthropometric meas- } \\
\text { ures from } 3,054 \text { children } \\
\text { younger than } 5 \text { years }\end{array}$ & $\begin{array}{l}\text { Housing, } \\
\text { education, employment } \\
\text { and access to health } \\
\text { services }\end{array}$ & $\begin{array}{l}\text { Detailed question- } \\
\text { naire for SES dietary } \\
\text { characteristics including } \\
\text { food consumption and } \\
\text { aggregate household } \\
\text { consumption }\end{array}$ & & $\begin{array}{l}\text { Maternal education, basic } \\
\text { housing conditions, ac- } \\
\text { cess to health services, } \\
\text { ethnicity, fertility, maternal } \\
\text { age and diet composi- } \\
\text { tion were independently } \\
\text { associated with stunting. } \\
\text { However, after controlling } \\
\text { for relevant covariates, } \\
\text { economic inequality at } \\
\text { the provincial scale had } \\
\text { a statistically significant } \\
\text { deleterious effect on } \\
\text { stunting }\end{array}$ \\
\hline
\end{tabular}


is that the poor are usually not well presented, because homeless, unemployed or migrants not speaking the dominant language are difficult to reach (27). Additionally, from data based on cross sectional surveys it is not possible to determine whether the associations observed are causal (28). Also, in studies that use self-reported data, social desirability reporting bias is possible (28) especially in the higher SES since the better-educated class is more likely to be conscious of desirable eating habits (27). Finally, it is clear that the majority of the studies regarding SES have been conducted in the western world resulting in lack of data from different socioeconomic structures such as East Europe, Asia, South America and Africa.

One alternative approach explaining the causal mechanisms through which SES generates health differences is life course framework SES (3). Establishing whether the social distribution of a disease occurs at different stages of life course using indicators that show accumulation of social disadvantage or examining whether one particular measure of SES relates more closely to an outcome, can point to the ephemeral nature of exposures related to a specific health outcome (3).

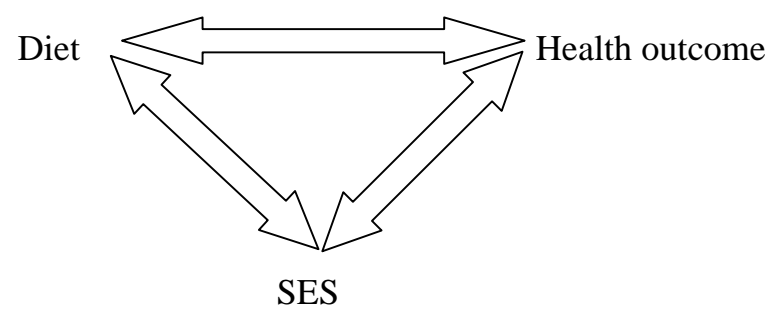

Fig. 1. The relationship between diet, SES, and human health

Finally, the role of SES as a mediator between diet and health has not been clearly investigated yet, as the majority of the studies directly relate SES with health outcomes or dietary habits. Then, indirectly, assume whether SES affects the causal relationship between diet and health (sequential relationship). For example, a lower SES is positively associated with a lower consumption of both fruit and vegetables (direct relationship with SES) and that suggests that an "unhealthy" nutrition pattern exists increasing the risk of chronic disease (indirect relationship with SES). Establishment of a model between SES (providing that it is adequately measured), diet and disease will clearly contribute to the understanding of SES as an explanatory variable in a direct and complex relationship between the three factors (Fig. 1.).

\section{REFERENCES}

1. Liberatos P, Link BG, Kelsey JL. The measurement of social class in epidemiology. Epidemiol Rev. 1988;10:87-121.

2. Krieger N, Williams DR, Moss NE. Measuring social class in US public health research: concepts, methodologies and guidelines. Annu Rev Public Health. 1997;18:341-78.

3. Galobardes B, Lynch J, Smith GD. Measuring socioeconomic position in health research. Br Med Bull. 2007 Jan;81-82(1):21-37.

4. Galobardes B, Morabia A, Bernstein M. Diet and socioeconomic position: does the use of different indicators matter? Int J Epidemiol. 2001 Apr;30(2):334-40.

5. Turrell G, Hewitt B, Patterson C, Oldenburg B. Measuring socio-eco- nomic position in dietary research: is choice of socio-economic indicator important? Public Health Nutr. 2003 Apr;6(2):191-200.

6. Winkleby MA, Jatulis DE, Frank E, Fortmann SP. Socioeconomic status and health: how education, income, and occupation contribute to risk factors for cardiovascular disease. Am J Public Health. 1992 Jun;82(6):816-20.

7. López-Azpiazu I, Sanchez-Villegas A, Johansson L, Petkeviciene J, Prattalaw R, Martinez-Gonzalez. Disparities in food habits in Europe: systematic review of educational and occupational differences in the intake of fat. J Hum Nutr Diet. 2003 Oct;16(5):349-64.

8. Turrell G, Kavanagh AM. Socio-economic pathways to diet: modelling the association between socio-economic position and food purchasing behaviour. Public Health Nutr. 2006 May;9(3):375-83.

9. Davey Smith G, Hart C, Hole D, MacKinnon P, Gillis C, Watt G, et al. Education and occupational social class: which is the more important indicator of mortality risk? J Epidemiol Community Health. 1998 May;52(3):153-60.

10. Wannamethee SG, Shaper AG. Socioeconomic status within social class and mortality: a prospective study in middle-aged British men. Int J Epidemiol. 1997 Jun;26(3):532-41.

11. Billson H, Pryer JA, Nichols R. Variation in fruit and vegetable consumption among adults in Britain. An analysis from the dietary and nutritional survey of British adults. Eur J Clin Nutr. 1999 Dec;53(12):946-52.

12. Irala-Estévez JD, Groth M, Johansson L, Oltersdorf U, Prättälä R, Martínez-González MA. A systematic review of socio-economic differences in food habits in Europe: consumption of fruit and vegetables. Eur J Clin Nutr. 2000 Sep;54(9):706-14.

13. Giskes K, Turrell G, Patterson C, Newman B. Socioeconomic differences among Australian adults in consumption of fruit and vegetables and intakes of vitamins A, C and folate. J Hum Nutr Diet. 2002 Oct;15(5):375-85.

14. Bartley M, Fitzpatric R, Firth D, Marmot M. Social distribution of cardiovascular disease risk factors: change among men in England 1984-1993. J Epidemiol Community Health. 2000 Nov;54(11):806-14.

15. Ball K, Mishra GD, Thane CW, Hodge A. How well do Australian women comply with dietary guidelines? Public Health Nutr. 2004 May;7(3):443-52.

16. Pollard J, Greenwood D, Kirk S, Cade J. Lifestyle factors affecting fruit and vegetable consumption in the UK Women's Cohort Study. Appetite. 2001 Aug;37(1):71-9.

17. Bolton-Smith C, Smith WC, Woodward M, Tunstall-Pedoe H. Nutrient intakes of different social-class groups: results from the Scottish Heart Health Study (SHHS). Br J Nutr. 1991 May;65(3):321-35.

18. Smith AM, Baghurst KI. Public health implications of dietary differences between social status and occupational category groups. J Epidemiol Community Health. 1992 Aug;46(4):409-16.

19. Mishra G, Ball K, Arbuckle J, Crawford D. Dietary patterns of Australian adults and their association with socioeconomic status: results from the 1995 National Nutrition Survey. Eur J Clin Nutr. 2002 Jul;56(7):687-93.

20. Panagiotakos DB, Pitsavos C, Stefanadis C. Dietary patterns: a Mediterranean diet score and its relation to clinical and biological markers of cardiovascular disease risk. Nutr Metab Cardiovasc Dis. 2006 Dec;16(8):559-68.

21. Perrin AE, Dallongeville J, Ducimetiere P, Ruidavets JB, Schlienger JL, Arveiler D, et al. Interactions between traditional regional determinants and socio-economic status on dietary patterns in a sample of French men. Br J Nutr. 2005 Jan;93(1):109-14.

22. Fung T, Hu FB, Fuchs C, Giovannucci E, Hunter DJ, Stampfer MJ, et al. Major dietary patterns and the risk of colorectal cancer in women. Arch Intern Med. 2003 Feb 10;163(3):309-14.

23. McNaughton SA, Mishra1 GD, Bramwell G, Paul AA, Wadsworth ME. Comparability of dietary patterns assessed by multiple dietary assessment methods: results from the 1946 British Birth Cohort. Eur J Clin Nutr. 2005 Mar;59(3):341-52.

24. Schulze MB, Hoffmann K, Kroke A, Boeing H. Dietary patterns and their association with food and nutrient intake in the European Prospective Investigation into Cancer and Nutrition (EPIC)-Potsdam study. Br J Nutr. 2001 Mar;85(3):363-73. Erratum in: Br J Nutr 2002 Mar;87(3):279.

25. Pomerleau J, Pederson LL, Ostbye T, Speechley M, Speechley KN. Health behaviours and socio-economic status in Ontario, Canada. Eur J Epidemiol. 1997 Sep;13(6):613-22.

26. Hazuda HP, Haffner SM, Stern MP, Eifler CW. Effects of acculturation and socioeconomic status on obesity and diabetes in Mexican Americans: The San Antonio Heart Study. Am J Epidemiol. 1988 Dec;128(6):1289-301.

27. Hulshof KF, Brussaard JH, AG Kruizinga, Telman J, Löwik MR. Socioeconomic status, dietary intake and $10 \mathrm{y}$ trends: the Dutch National Food Consumption Survey. Eur J Clin Nutr. 2003 Jan;57(1):128-37.

28. Ball K, Crawford D, Mishra G. Socio-economic inequalities in women's fruit and vegetable intakes: a multilevel study of individual, social and environmental mediators. Public Health Nutr. 2006 Aug;9(5):623-30. 
29. Kwasniewska M, Bielecki W, Drygas W. Sociodemographic and clinical determinants of quality of life in urban populations of Poland. Cent Eur J Public Health. 2004 Jun;12(2):63-8.

30. Indulski JA, Rolecki R. Industrialization and environmental health in Poland. Cent Eur J Public Health. 1995 Feb;3(1):3-12.

31. Zejda JE, Grabecki J, Król B, Panasiuk Z, Jedrzejczak A, Jarkowski M. Blood lead levels in urban children of Katowice Voivodship, Poland: results of the population-based biomonitoring and surveillance program. Cent Eur J Public Health. 1997 Jun;5(2):60-4.

32. Pikhart H, Príkazský V, Bobák M, Kř́̌̌ B, Čelko M, Dáňová J, et al. Association between ambient air concentrations of nitrogen dioxide and respiratory symptoms in children in Prague, Czech Republic. Preliminary results from the Czech part of the SAVIAH study. Small Area Variation in Air Pollution and Health. Cent Eur J Public Health. 1997 Jun;5(2):82-5.

33. Bobák M, Dáňová J, Křŕž B. Socio-economic factors and growth of preschool children attending nurseries in Prague, Czech Republic. Cent Eur J Public Health. 1994 Jun;2(1):9-12.

34. Drachler Mde L, Bobák M, Rodrigues L, Aertz DR, Leite JC, Dáňová J, et al. The role of socioeconomic circumstances in differences in height of pre-school children within and between the Czech Republic and southern Brazil. Cent Eur J Public Health. 2002 Dec;10(4):135-41.

35. Príkazský V, Kubín M, Pikhartová J. Selected results of the tuberculosis control program in the Czech Republic. Cent Eur J Public Health. 1999 Dec;7(3):116-21.

36. Murphy M, Bobák M, Nicholson A, Rose R, Marmot M. The widening gap in mortality by educational level in the Russian Federation, 19802001. Am J Public Health. 2006 Jul;96(7):1293-9.

37. Bittó A, Horváth A, Sárkány E. Monitoring of blood lead levels in Hungary. Cent Eur J Public Health. 1997 Jun;5(2):75-8.

38. Puhó E, Métneki J, Czeizel AE. Maternal employment status and isolated orofacial clefts in Hungary. Cent Eur J Public Health. 2005 Sep;13(3):144-8.

39. Kobzová J, Vignerová J, Bláha P, Krejčovský L, Riedlová J. The 6th nationwide anthropological survey of children and adolescents in the Czech Republic in 2001. Cent Eur J Public Health. 2004 Sep;12(3):126-30.

40. Islam MZ, Lamberg-Allardt C, Kärkkäinen M, Ali SM. Dietary calcium intake in premenopausal Bangladeshi women: do socio-economic or physiological factors play a role? Eur J Clin Nutr. 2003 May;57(5):674-80.

41. Dien le N, Thang NM, Bentley ME. Food consumption patterns in the economic transition in Vietnam. Asia Pac J Clin Nutr. 2004;13(1):40-7.

42. Tian HG, Hu G, Dong QN, Yang XL, Nan Y, Pietinen P, et al. Dietary sodium and potassium, socioeconomic status and blood pressure in a Chinese population. Appetite. 1996 Jun;26(3):235-46.

43. Shi Z, Lien N, Kumar BN, Holmboe-Ottesen G. Socio-demographic differences in food habits and preferences of school adolescents in Jiangsu Province, China. Eur J Clin Nutr. 2005 Dec;59(12):1439-48.

44. Larrea C, Kawachi I. Does economic inequality affect child malnutrition? The case of Ecuador. Soc Sci Med. 2005 Jan;60(1):165-78.

Received February 11, 2008

Accepted in revised form Decembers 5, 2008 